\title{
PATŘÍ PROJEKTY OBČANSKÉ VĚDY DO MUZEÍ?
}

\section{PETRA CALTOVÁ - ZDEŇKA KULHAVÁ - FRANTIŠEK TYMR}

\section{ABSTRAKT/ABSTRACT:}

Občanská věda, tedy aktivní zapojení dobrovolníků z řad široké veřejnosti do procesu vědeckého bádání, je v pamětových institucích stále častěji využívaným výzkumným př́stupem. Pro muzea představuje významnou př́ležitost prezentovat svou činnost širší komunitě zájemců. Oproti př́rodovědným jsou občanskovědní projekty $\mathrm{v}$ humanitních oborech zastoupeny marginálně.

Předkládaná studie si mimo jiné klade za cíl popsat možné prričiny tohoto nerovnoměrného zastoupení. Součástí je také rešerše tuzemských i zahraničních př́íkladů dobré praxe, stejně jako nastínění kladných a záporných stránek občanskovědních projektů a jejich metodologie.

\section{Do citizen science projects belong into museums?}

Citizen science, the active involvement of volunteers from the general public in the process of scientific research, is an increasingly used research approach in memory institutions. It represents an important opportunity for museums to present their activities to a wider community of people with common interest. Contrary to natural sciences, citizen science projects are marginally represented in the humanities. Presented study aims,

1 Předložená práce vznikla za finanční podpory hl. m. Prahy a Ministerstva kultury v rámci institucionálního financování dlouhodobého koncepčního rozvoje výzkumné organizace Národní muzeum (DKRVO 2019-2023/26.I.b, 00023272). among other goals, to describe the possible causes of this uneven representation. It also includes a variety of domestic and foreign examples of good practice, as well as an outline of the positive and negative aspects of citizen science projects and their methodology.

\section{KLÍČOVÁ SLOVA/KEYWORDS:}

občanská věda - veřejnost muzeum - neformální vzdělávání motivace

citizen - science - public - museum informal education - motivation

\section{Občanská věda}

Světové muzejnictví si za posledních 50 let začalo hledat různé cesty, jak se vydat vstřríc návštěvníkům. Mění svůj směr a výstupy cílí stále více na širokou veřejnost. Pamětové instituce odstupují od projektů zaměřených striktně na komunitu odborníků, jak tomu bylo dřive. Vznikají výstavy, jejichž výsledná podoba je ovlivněna očekáváními, zkušenostmi i emocemi veřejnosti. Věda a výzkum stále zůstává jednou z hlavních činností muzeí, avšak př́stup $\mathrm{k}$ nim se podobně jako v jiných vědeckých institucích mění a vyvíjí. Ve vědecké i výstavní činnosti světová muzea zohledňují očekávání, zkušenosti, názory i emoce návštěvníků a jsou otevřena spolupráci. Aktivní zájem veřejnosti o svou činnost vítají a rozvíjejí jej. ${ }^{2} \mathrm{~V}$ důsledku toho ji vtáhnou do dění, čímž

2 SIMON, Nina. The participatory museum. Santa Cruz: Museum 2.0, 2010. legitimizují svou existenci. U některých muzeí lze hovořit přímo o tom, že se stávají komunitními centry. ${ }^{3}$ Jejich prvním vykročením směrem $\mathrm{k}$ veřejnosti v České republice se stal projekt Brána muzea otevřená realizovaný v letech 1997-2002. ${ }^{4}$ Díky tomuto projektu se v muzejním prostředí začal více akcentovat zájem o návštěvníka, a to co od své návštěvy pamětové instituce očekává. Také během této doby vznikly desítky projektů zaměřených na edukaci $v$ muzeích. $\mathrm{V}$ následujících dvaceti letech se muzea odvážila k projektům, zapojujícím laickou veřejnost do vědeckých úkolů.

Stále populárnějšími jsou projekty tzv. občanské vědy (dále OV). Jedná se o proces, kdy nevědečtí dobrovolníci sbírají a/ nebo zpracovávají data $\mathrm{v}$ rámci vědeckého výzkumu. ${ }^{5}$ OV nabízí zajímavou př́ležitost, jak propojit odborné pracovníky a širokou veřejnost ve společné aktivitě řešení vědeckého projektu. Detailnější charakteristice OV se věnuje Evropská asociace občanské vědy, ${ }^{6}$ která definuje řadu možností

\footnotetext{
3 KULHAVÁ, Zdeňka. Muzejní pedagog jako klíčový nástroj v komunikaci s veřejností. In KOCICHOVÁ, Ivana a Marie ŽÁČKOVÁ (eds.). Strážci paměti: 200 let muzejnictví v České republice. Perspektivy české muzejní edukace. Sborník př́spěvků z konference. Praha: Národní museum, 2016, s. 21-30.

4 BRABCOVÁ, Alexandra (ed.). Brána muzea otevřená. Náchod: JUKO, 2003.

5 SILVERTOWN, Jonathan. A New Dawn for Citizen Science. Trends in Ecology \& Evolution, 2009, roč. 24, č. 9, s. 467-471.

6 We are ESCA [online]. Berlin: European Citizen Science Association (ESCA), 2020 [cit. 2021-01-23]. Dostupný z www: $<$ https://ecsa.citizen-science.net/ $>$.
} 
zapojení veřejnosti do procesu bádání. Podobně uvádí Haklay čtyři úrovně zapojení účastníků do občanskovědních projektů:?

- crowdsourcing: účastníci sbírajî data bez nutných odborných znalostí

- s přispěním veřejnosti: účastníci se po základním zaškolení podílejí na sběru dat a jejich vyhodnocování

- $\quad$ se spoluúčastí veřejnosti: účastníci se podílí na definování hypotézy, sběru dat a vyhodnocení pod odborným vedením

- s úplným zapojením veřejnosti: účastníci jsou rovnocennými partnery vědeckých pracovníků. Plně se podílejí na všech úrovních vědeckého bádání.

Ačkoliv je termín OV ve spojitosti $s$ vědeckými výstupy stále více skloňován až v posledních letech, nejedná se o novinku současné doby. Jeden z prvních známých projektů se konal v USA již v roce 1849. Jednalo se o zaznamenávání meteorologických jevi̊ sto padesáti dobrovolníky. ${ }^{8}$ Od té doby probíhalo mnoho dlouhodobých projektů postavených na spolupráci nevědecké a odborné veřejnosti, které nesly různá nejednotná označení. ${ }^{9}$ Sjednocení pod společný

7 HAKLAY, Muki. Citizen Science and Volunteered Geographic Information - overview and typology of participation. In SUI, Daniel Z., Sarah ELWOOD a Michael F. GOODCHILD (eds.). Crowdsourcing Geographic Knowledge: Volunteered Geographic Information (VGI) in Theory and Practice. Berlin: Springer, 2013, s. 105-122.

8 COOPER, Caren. Life, Liberty, and Pursuit of Data: The Public Trust of Museum-Based Citizen Science. The Affiliate. News about Smithsonian Affiliates, 2017, č. 4, s. 1-3.

9 CAVALIER, Darlene, Catherine HOFFMAN a Caren COOPER. The Field Guide to Citizen Science: How You Can Contribute to Scientific Research and Make a Difference. Portland: Timber Press, 2020; Citizen Science Terminology Matters: Exploring Key Terms. Citizen Science: Theory and Practice [online], roč. 2, č. 1, 2017 [cit. 2021-01-23]. Dostupný z www: <https://

theoryandpractice.citizenscienceassociation. název má za následek sloučení podobně řešených projektů, vytvoření společných zdrojů a metodik.

Avšak ne každé zapojení veřejnosti lze považovat za OV. Evropská asociace občanské vědy sestavila deset principů, které vymezují rámec těchto projektů. Mimo jiné charakterizuje OV jako jakýkoliv jiný výzkumný přístup, kde je potřeba definovat hypotézu, postupovat systematicky, nasbíraná data vyhodnotit a publikovat, a to ideálně $s$ otevřeným přístupem. ${ }^{10}$

Cílem této studie je nastínit, jaký má občanská věda v muzejnictví potenciál bez ohledu na to, jestli se jedná o př́írodovědně nebo humanitně zaměřené instituce. Zároveň chce na konkrétních prríkladech realizovaných občanskovědních projektů v tuzemsku i zahraničí ukázat, že lze prohloubit aktivity v tomto směru právě $\mathrm{v}$ humanitním, případně technickém odvětví. Autoři textu si pokládají i otázku motivace dobrovolníků nejen k zapojení do aktivit, ale $\mathrm{k}$ jejich dlouhodobé spolupráci. Ta je totiž klíčovým prvkem úspěšného projektu. Zároveň si studie klade za cíl rozšířit povědomí o občanské vědě v českém muzejnictví a vzbudit případný zájem ostatních kolegů o tuto metodu práce s veřejností.

\section{Možnosti občanské vědy}

Kromě sběru dat a získávání nových vědeckých poznatků si OV klade za cíl především

\footnotetext{
org/articles/10.5334/cstp.96/>; Občanská věda: její význam a motivace účastníků v návaznosti na projekt City Nature Challenge. Journal of the National Museum, Natural History Series, 2020, č. 189, s. 49-64; SIMON, Nina. The participatory museum. Santa Cruz: Museum 2.0, 2010.

10 Deset principů občanské vědy [online]. Berlin: European Citizen Science Association (ESCA), 2020 [cit. 2021-01-23]. Dostupný z www: $<$ https://ecsa.citizen-science.net/wp-content/ uploads/2020/02/ecsa_ten_principles_of_cs_ czech.pdf $>$.
}

popularizaci vědy, jejích výstupů a obecně vzdělávání veřejnosti. ${ }^{11}$ Aktivní účast v občanskovědním projektu vede ke zlepšení znalostí studovaného oboru, pochopení souvislostí týkajících se průběhu vědeckého bádání a významu vědecké práce vůbec. Někteří autoři dokonce uvádějí změny v chování účastníků na základě nově nabytých vědomostí a schopností. ${ }^{12}$ Do metodicky jednodušších projektů se může zapojit širší komunita dobrovolníků bez nutnosti intenzivního zaškolení, což je činí efektivnějšími v porovnání s komplikovanějšími projekty. ${ }^{13}$

$\mathrm{V}$ poslední době jsou užitečnou pomůckou v projektech OV moderní technologie. Právě jejich využití umožňuje zapojení široké veřejnosti, sběr enormního množství dat a zároveň jejich zpracování. Současně je to vhodný nástroj po komunikaci s dobrovolnickou komunitou navázanou na konkrétní projekt.

Slabou stránkou takovýchto projektů může být nižší kvalita a nekonzistentnost získaných dat. Toto riziko je možné minimalizovat vhodně nastaveným designem projektu a dostatečným zaškolením účastníků z řad široké veřejnosti.

\footnotetext{
11 Citizen Science: A Developing Tool for Expanding Science Knowledge and Scientific Literacy. BioScience, 2009, roč. 59, č. 11, s. 977-984; The Current State of Citizen Science as a Tool for Ecological Research and Public Engagement. Frontiers in Ecology and the Environment, 2012, roč. 10, č. 6, s. 291-297.

12 Contributions to conservation outcomes by natural history museum-led citizen science: Examining evidence and next steps. Biological Conservation, 2017, č. 208, s. 87-97; HSU ChiaHsuan, Yuan-Mou CHANG a Chi-Chang LIU. Can Short-Term Citizen Science Training Increase Knowledge, Improve Attitudes, and Change Behavior to Protect Land Crabs? Sustainability, 2019, roč. 11, č. 14, s. 3918; Citizen Science in School. In COSTA Manuel F., Josep M. FERNÁNDEZ-NOVELL a José B. V. DORRÍO (eds.). Hands-on science: advancing science, improving education. Braga: Hands-on Science Network, 2018, s. 194-198.

13 Choosing and Using Citizen Science: a guide to when and how to use citizen science to monitor biodiversity and the environment. Wallingford: Centre for Ecology \& Hydrology, 2014.
} 
I přes možná negativa se OV stává uznávanou formou sběru a zpracování dat ve stále větším procentu vědních oborů.

\section{Motivace účastníků}

Principem OV je dobrovolné zapojení se široké veřejnosti do vědeckého bádání. $\mathrm{Z}$ toho důvodu je základním kamenem úspěšných projektů jejich dobře navržený design s významným zaměřením na motivaci účastníků, bez které nevznikne dostatečně silná komunita dobrovolníků. ${ }^{14}$ Navíc nestačí jen širokou veřejnost přesvědčit, aby se zapojila, ale především ji motivovat k udržení aktivity po celou dobu konání projektu. $^{15}$

Díky využití moderních technologií probíhá komunikace nejen se stávajícími účastníky, ale dochází i k předání informací o projektu potenciálním novým zájemcům. Motivace dobrovolníků obecně roste, pokud se řešená problematika týká jejich bezprostředního okolí nebo jich samotných. ${ }^{16}$ Důležitá je také míra zapojení účastníků do procesu bádání. Motivace se bude zvyšovat, pokud získají informace o významu a průběhu projektu a dostatečně jim porozumí. $\mathrm{V}$ důsledku toho se pak velice pravděpodobně zapojí i do celkově složitějších a náročnějších procesů. ${ }^{17}$ Jako klíčový je často uváděn

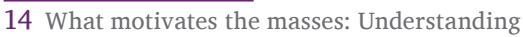
why people contribute to conservation citizen science projects. Biological Conservation, 2020, sv. 246, čl. 108587.

15 KAUFMANN, Imke a Monika HAGEDORNSAUPE. Citizen Science in Humanities / Unlocking the Knowledge of the Crowd. In WIMM+ Virtual Multimodal Museum [online]. Lemesos: Cyprus University of Technology Cyprus, 2017 [cit. 2021-01-23]. Dostupný z www: <https:// www.vi-mm.eu/wp-content/uploads/2018/05/ Citizen-Science-Paper_AP_IK_MHS_final.pdf $>$.

16 FALK, John H. (ed.). Free-choice science education: How we learn science outside of school. New York: Teachers College Press, 2001.

17 Choosing and Using Citizen Science: a guide to when and how to use citizen science to monitor biodiversity and the environment. Wallingford: Centre for Ecology \& Hydrology, 2014.
}

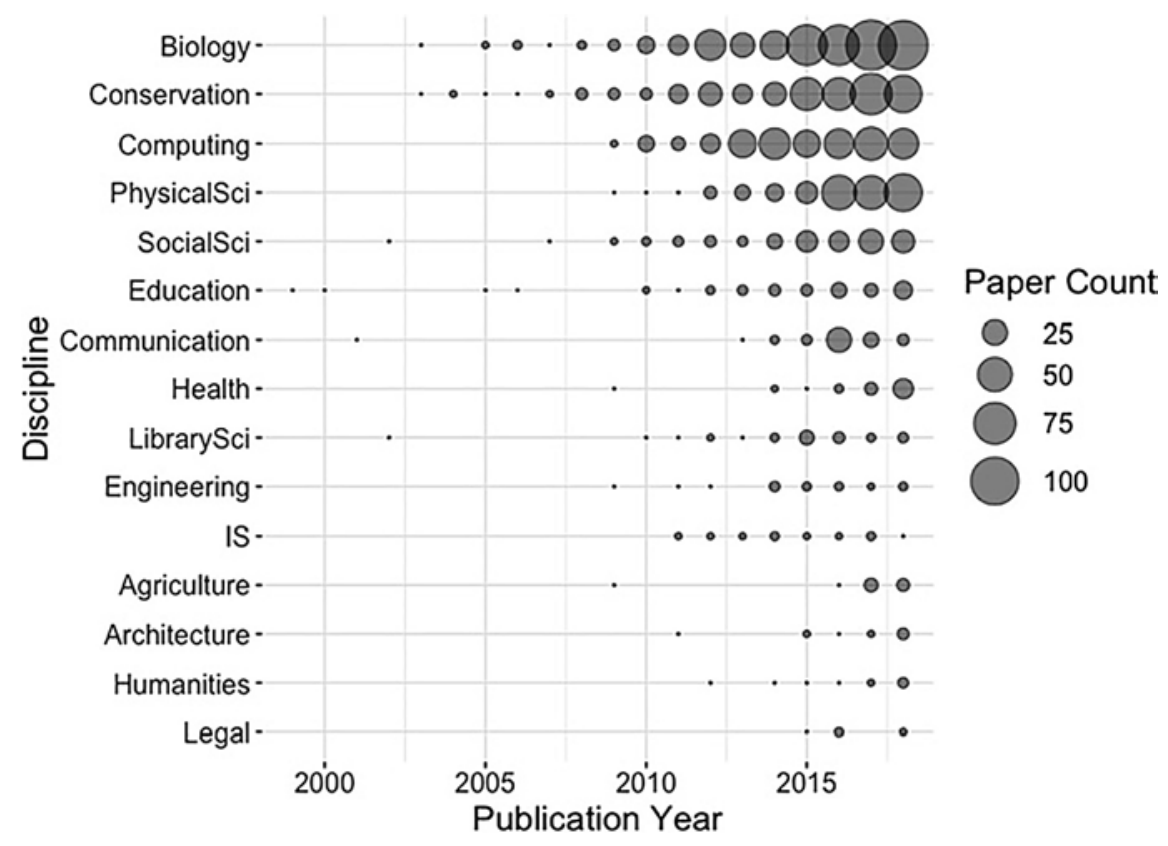

Obr. 1: Grafické znázornění publikovaných studií v oblasti občanské vědy napříč obory v průběhu času. ${ }^{24}$

zájem o danou problematiku, snaha pomoci s vyřešením zajímavého úkolu, ale také př́íležitost socializovat se..$^{18}$ Někteří účastníci vítají možnost řešit společně problémy se známými a př́ibuznými, jiné motivuje př́ležitost pracovat $\mathrm{v}$ komunitě lidí se sdíleným zájmem. ${ }^{19}$

Dobře motivovaní účastníci budou spokojenými spoluřešiteli, kteří začnou samovolně šířit informace o projektu svému okolí a v ideálním př́ípadě tak rozšiřovat komunitu zapojených dobrovolníků. ${ }^{20}$

\section{Občanská věda napříč obory}

Původně byly projekty OV spojovány čistě s př́rodními vědami. Dnes jsou využívány ve

\footnotetext{
18 Občanská věda: její význam a motivace účastníků v návaznosti na projekt City Nature Challenge. Journal of the National Museum, Natural History Series, 2020, č. 189, s. 49-64.

19 Motivations for Committed Nature Conservation Action in Europe. Environmental Conservation, 2017, roč. 44, č. 2, s. 148-157.

20 What motivates the masses: Understanding why people contribute to conservation citizen science projects. Biological Conservation, 2020, roč. 246, čl. 108587.
}

většině oblastí lidského poznání, ${ }^{21}$ i když v některých oborech $\mathrm{k}$ tomu dochází zatím minoritně. Průzkum uskutečněný v Evropě odhalil, že 83,2 \% občanskovědních projektů bylo realizováno $\mathrm{v}$ přírodních vědách, 5,8 \% v technicky zaměřených oborech a pouze $11 \%$ ve společenských a humanitních vědách. ${ }^{22}$ Podobné výsledky prezentuje ve svých studiích více autorů ${ }^{23}$ stejně jako autoři z Univerzity Tomáše Bati ve Zlíně,

21 DUŽÍ, Barbora a Jakub TROJAN. E-manuál komunikace občanské vědy a vybrané př́íklady dobré praxe. In Občanská věda v České republice [online]. Brno: Ústav geoniky AV ČR, v. v. i., 2020 [cit. 2021-01-23]. Dostupný z www:

<https://www.citizenscience.cz/wp-content/ uploads/2020/09/CS_komunikace_e-manual_fin. pdf $>$.

22 HECKER, Susanne, Lisa GARBE a Aletta BONN. The European citizen science landscape a snapshot. In Citizen Science: Innovation in Open Science, Society and Policy. London: UCL Press, 2018, s. 190-200.

23 FRANZONI, Chiara a Henry SAUERMANN. Crowd science: The organization of scientific research in open collaborative projects. Reasearch Policy, 2014, roč. 43, č. 1, s. 1-20; LUKYANENKO, Roman, Andrea WIGGINS a Holly K. ROSSER.

Citizen Science: An Information Quality Research Frontier. Information Systems Frontiers, 2020, č. 22, s. 961-983.

24 LUKYANENKO, Roman, Andrea WIGGINS a Holly K. ROSSER. Citizen Science: An Information Quality Research Frontier. 
kteří na webových stránkách www. citizenscience.cz shromažd'ují informace o projektech OV na území České republiky. Podobnou funkci má mezinárodní vyhledávač SciStarter. ${ }^{25}$

\section{Občanská věda v technických oborech}

Technické obory se objevují v občanskovědních projektech velmi zřídka. Jak bylo zmíněno výše, technika, at už formou různých algoritmů, softwarů nebo hardwarů je součástí většiny občanskovědních aktivit. Zapojení veřejnosti do projektů technického odvětví je vzhledem k jejich náročnosti komplikované, v důsledku toho probíhají projekty OV na úrovni crowdsourcingu nebo se zapojením veřejnosti (viz výše). Není tedy žádný rozdíl v metodách práce $\mathrm{v}$ tomto odvětví ve srovnání s ostatními oblastmi (viz níže). Jako příklad je možné uvést projekt Města $v$ noci (Cities at Night), který se zaměřuje na mapování světa díky obrovskému množství fotografií pořízených astronauty NASA během jejich misí do vesmíru. Při takových cestách vznikají statisíce snímků, které nemá NASA čas katalogizovat. Proto zapojila veřejnost do výzvy pomoci s tříděním snímků a jejich lokalizováním. Tato aktivita pomůže sekundárně ve studiu světelného znečištění. ${ }^{26}$

\section{Občanská věda v humanitních oborech}

V případě občanskovědních projektů v humanitních vědách se zpravidla jedná o projekty založené

\footnotetext{
Information Systems Frontiers, 2020, č. 22, s. 961-983.

25 GOFORTH, Christine L. Getting started in Citizen Science. The Affiliate. News about Smithsonian Affiliates, 2017, č. 4, s. 7; SciStarter, science we can do together [online]. Tempe: Arizona State University, 2021 [cit. 2021-01-23]. Dostupný z www: <https://scistarter.org/>.

26 Lost at night [online]. Cities at night, 2021 [cit. 2021-01-18]. Dostupný z www: <https://

lostatnight.org/>
}

na práci v online platformách, kdy se dobrovolníci aktivně zapojují do tvorby virtuálních databází nebo shromažd’ují informace na sociálních sítích. Na vyhodnocení dat se podílejí pouze odborní pracovníci institucí organizujících konkrétní projekty. ${ }^{27} \mathrm{~V}$ humanitně zaměřených občanskovědních projektech se dobrovolníci většinou nepodílejí ani na sestavování výzkumných otázek, metodologii projektu nebo závěrečné diskusi. ${ }^{28}$ Jedná se tedy zpravidla o aktivity na úrovni crowdsourcingu, případně s přispěním veřejnosti.

\section{R. Heiss a J. Matthes předložili} ve svém článku ${ }^{29}$ několik tezí, proč jsou humanitní vědy oproti přírodním v OV upozaděné. Jednou z možných př́ičin je komplikovanost jejich obsahu, resp. interpretace pozorované skutečnosti. Samotná odborná obec není jednotná v pohledu na možnosti pozorování zkoumaných jevů. Ta část odborníků, která považuje za reálné pracovat $\mathrm{v}$ humanitních vědách metodami přírodních věd, tvrdí, že je možné na jejich principu pozorovat a vyhodnocovat skutečnost i v nepřírodovědných oblastech. Jejich odpůrci, zastánci hermeneutického směru, oponují tím, že je svět konstruován skrze lidské vnímání a jeho analýzu umožňuje proces interpretace, čímž se do diskuse dostává míra dosažitelné objektivity.

Dále Heiss a Matthes definují tř̌i limity, s nimiž se OV v humanitních oborech potýká. Prvním z nich

\footnotetext{
27 Citizen science in the social sciences and humanities: the power of interdisciplinarity. Palgrave Communications, 2020, roč. 6, čl. 89.

28 DOBREVA, Milena a Daniela AZZOPARDI. Citizen Science in the Humanities: A Promise for Creativity. In PAPADOPOULOS, George A. (ed.). Proceedings of the 9th International Conference on Knowledge, Information and Creativity Support Systems, Limassol, Cyprus, November 6-8, 2014. Berlin: Springer, 2016, s. 446-451.

29 HEISS, Raffael a Jörg MATTHES. Citizen Science in the social sciences: A Call for More Evidence. Ecological Perspectives for Science and Society, 2017, roč. 26, č. 1, s. 22-26.
}

je otázka aktivizace cílových skupin. Není mnoho volnočasových uskupení, jejichž předmětem zájmu jsou společenské vědy. Zároveň, co se výchovy budoucích dobrovolníků týče, se děti s nimi na základních školách seznamují velmi okrajově. Z hlediska jakéhokoli výzkumu prakticky nulově. Metody práce ve společenských vědách nejsou tak jednoduché na vysvětlení, jako je tomu například u přírodovědných pozorování. Interpretace závěrů výzkumu v humanitních oborech je hodně závislá na samotném kontextu, učiněná pozorování jsou často neopakovatelná. Např. opakovaný rozhovor s pamětníkem nikdy nebude totožný, ale měření kvality vody ve vodní nádrži lze zopakovat nesčetněkrát. Dalším aspektem může být vztah mezi lidským pozorováním a kvalitou získaných dat. I přes sebelepší zaškolení dobrovolníků nelze vyloučit vliv vnímání jednotlivce na popis pozorovaného jevu. ${ }^{30}$ Poslední, avšak neméně důležitou otázkou, je morálka. U humanitně zaměřených občanskovědních projektů je etika výzkumu mnohem náročnější než u přírodních věd. S tím souvisí i nakládání s citlivými daty jako jsou osobní údaje, ale i mezilidské vztahy, politické názory, životní postoje, víra apod.

I když většina autorů uvádí minimální využití projektů OV v humanitních vědách, $v$ českém prostředí lze zmínit hned několik př́kladů dobré praxe. Jedním z nich je projekt Europeana 1989, kterého se zúčastnilo roku 2014 Národní muzeum. Jeho cílem bylo díky zapojení veřejnosti získat autentická svědectví a obohatit muzejní sbírky o předměty vážící se $\mathrm{k}$ listopadovým událostem roku 1989. Výstupy projektu

\footnotetext{
$30 \mathrm{Z}$ hlediska rizik objektivity interpretace skutečnosti v oblasti humanitních věd viz studie KULHAVÁ, Zdeňka. Pamětník jako cenný zdroj informací i Achillova pata historikova. Možnosti využití orální historie při studiu událostí druhé světové války. In Ústecký sborník historický, 2017, roč. 8 , č. 1-2 (v tisku)
} 
byly formou fotografií a přepisů rozhovorů publikovány na webových stránkách projektu Europeana prostřednictvím portálu Národního muzea eSbírky. ${ }^{31}$

Dalším příkladem jsou Staré mapy. Projekt byl realizován $\mathrm{v}$ roce 2013 osmnácti institucemi (muzei, archivy, univerzitami a knihovnami) sdruženými pod vedením Moravské zemské knihovny. Cílem bylo pomocí georeferencování zvýšit úroveň zpřístupnění digitalizovaných mapových sbírek v České republice. ${ }^{32}$ Dobrovolníci, kteří se registrovali do svých účtů na webových stránkách projektu, porovnávali historické mapy se současnými a doplňovali názvy míst existujících dříve a nyní. Atraktivitu projektu zvyšovala možnost překrývat více map přes sebe, sledovat proměnu území $\mathrm{v}$ čase nebo vytvořit na Google Earth zajímavou 3D vizualizaci. Instituce na oplátku získaly metadata, která doplnily do svých evidenčních systémů.

Ze zahraničí můžeme uvést crowdsourcingový projekt uskutečněný díky Trinity College Univerzity v Dublinu v rámci Centra pro digitalizaci humanitních věd (Center for Digital Humanities). Jednalo se o aktivitu celosvětového dosahu, jejímž cílem bylo shromáždit dopisy od Irů nebo jim adresovaných, vztahujících se k roku 1916. Výsledky poodhalily podrobnosti týkající se životního stylu lidí v roce 1916 a vytvořily

\footnotetext{
31 Výroční zpráva 2014 - Projekt Europeana představí památky na rok 1989 [online]. Praha: Národní museum, 2021 [cit. 2021_01_02]. Dostupné z www: < http://vyrocnizpravy. nm.cz/2014/sbirkotvorna-cinnost/projekteuropeana-predstavi-pamatky-na-rok-1989. html >; eSbírky - kulturní dédictví on-line [online]. Praha: Národní muzeum, 2021 [cit. 2021-01-02]. Dostupný z www: <htttp://www.esbirky.cz/>

32 Staré mapy.cz [online]. Brno: Moravská zemská knihovna, 2013 [cit. 2021_01_02]. Dostupný z www: <https://www.staremapy.cz/projekt/>.
}

nový pohled na život na počátku 20. století. $^{33}$

V souvislosti s výše uvedenou aktivitou Staré mapy uspořádanou v ČR lze uvést zahraniční projekt, který se konal pod záštitou Britské knihovny. Ta oslovila veřejnost s prosbou o shromáždění a digitalizaci historických map nejen Velké Británie. Výsledky projektu jsou stále dostupné online na webových stránkách knihovny. ${ }^{34}$ Podařilo se shromáždit šedesát dva map na různých nosičích, at’ už v papírové podobě ve formě manuskriptů, rytin, na globech nebo i v rámci společenské hry.

Právě spojení s herní aktivitou je dobrou motivací pro účastníky. V projektu ARTigo získávají historici umění Ludwig-Maxmiliánovy univerzity v Mnichově klíčová slova (tagy) k popisu uměleckých děl od veřejnosti. Organizátoři nabídli veřejnosti rozsáhlou online galerii uměleckých děl a z nich vycházející online hru. Dva hráči vymýšlí nezávisle na sobě klíčová slova popisující umělecké dílo a dostávají body na základě shody. Projekt rozšiřuje povědomí veřejnosti o uměleckých dílech a zároveň odborníkům poskytuje data o tom, jak jsou umělecká díla vnímána současným divákem. ${ }^{35}$

\section{V letech 2014-2016 realizoval již výše zmiňovaný prof. Matthes se svými studenty na Institutu pro}

33 DOBREVA, Milena a Daniela AZZOPARDI. Citizen Science in the Humanities: A Promise for Creativity. In PAPADOPOULOS, George A. (ed.) Proceedings of the 9th International Conference on Knowledge, Information and Creativity Support Systems, Limassol, Cyprus, November 6-8, 2014. Berlin: Springer, 2016, s. 446-451; na webových stránkách Digital Humanities at Trinity College Dublin [online], [cit. 2021-01-21] dostupné informace o projektu již nejsou dohledatelné na www: <https://dh.tcd.ie/>.

34 British Library - Maps [online]. London: The British Library, 2021 [cit. 2021-01-02]. Dostupný z www: <https://www.bl.uk/maps/\#>.

35 Play Artigo, the crowsourcing game of art history [online]. Citizen Science Games, 2019 [cit. 2021-01-18]. Dostupný z www: <https:// citizensciencegames.com/games/artigo/ > . mediální a komunikační studia Vídeňské univerzity občanskovědní projekt YAPES - Young Adults“ Political Experience Sampling zaměřený na kategorizování politických zkušeností mladých lidí. Dobrovolníci byli vyzváni, aby každý den zaznamenávali své zkušenosti vztahující se k politice a posílali je formou fotografií s popiskem výzkumnému týmu prostřednictvím e-mailu nebo aplikace WhatsApp. Referovali tak o všem, co je pro ně politicky zajímavé. Díky shromážděným datům bylo zjištěno, jaké politické problémy řeší mladí lidé v každodenním životě a jak se jich politika dotýká. ${ }^{36}$

\section{Občanská věda $\mathbf{v}$ přírodovědných oborech}

Je pravděpodobné, že se většina projektů OV zaměřuje právě na přírodní vědy především proto, že se tyto studie odehrávají v bezprostředním okolí uchazečů. ${ }^{37}$ Nabízejí jim možnost zapojit se do nové aktivity a zároveň $\mathrm{z}$ jiného úhlu prozkoumat vlastní okolí. Často se jedná o projekty spojené $\mathrm{s}$ pobytem $\mathrm{v}$ přírodě, at' už na vlastní zahradě, v nejbližším lese nebo odehrávající se na obloze. Většinou nebývá potřeba hlubší školení účastníků a cílové kategorie proto jsou téměř neomezené. Podle konkrétního zaměření a designu projektu se účastníci zapojují nejčastěji do sběru dat, ale nejsou výjimkou projekty se spoluúčastí nebo s plným zapojením veřejnosti. Nejčastějšími obory, kde se OV stává již tradiční metodou sběru a zpracování dat jsou biologie, vědy o Zemi,

\footnotetext{
36 YAPES - Young Adults' Political Experience Sampling [online]. Wien: Universität Wien, 2021 [cit. 2021_01_02]. Dostupný z www: $<$ https://citizenscience.univie.ac.at/projektean-der-universitaet-wien/yapes-young-adultspolitical-experience-sampling/>.

37 Citizen Science in Hydrological Monitoring and Ecosystem Services Management: State of the Art and Future Prospects. Science of The Total Environment, 2019, č. 693, čl. 133531.
} 
v poslední době také astronomie nebo antropologie. ${ }^{38}$ Velké množství projektů se zaměřuje na monitoring biodiverzity, vliv člověka na přírodu, ${ }^{39}$ sledování kvality životního prostředí, ${ }^{40}$ pozorování astronomických jevů apod. V zahraničí existují stovky projektů zaměřujících se na monitoring biodiverzity nebo ohrožených ${ }^{41}$ či invazivních druhů. ${ }^{42}$ Zajímavou aktivitou je StrawbAIRries, projekt pro lepší kvalitu vzduchu organizovaný Univerzitou v Antverpách. Na designu tohoto komunitního projektu spolupracovali univerzitní zaměstnanci a dobrovolníci $\mathrm{z}$ řad široké veřejnosti. Jedná se o monitoring znečištění ovzduší v kombinaci s pozorováním opylovačů. Každý zájemce získá laboratorně pěstovanou sazenici jahodníku obecného. Zároveň obdrží instrukce, jak se o rostlinu na vlastním parapetu starat. Kromě klasické péče o rostlinu účastník pozoruje a zaznamenává počet květů a plodů rostliny a také druhy hmyzu, které rostlina přiláká. V daném období zasílá list rostliny

38 LUKYANENKO, Roman, Andrea WIGGINS a Holly K. ROSSER. Citizen Science: An Information Quality Research Frontier. Information Systems Frontiers, 2020, č. 22 s. 961-983; HAND, Eric. People power. Nature, 2010, roč. 466, č. 5, s. 685-687.

39 STELLE, Lei Lani. Using Citizen Science to Study the Impact of Vessel Traffic on Marine Mammal Populations. In CIGLIANO, John A. a Heidi L. BALLARD (eds.). Citizen Science for Coastal and Marine Conservation. London: Routledge, 2017; DEVICTOR, Vincent, Robert J. WHITTAKER a Coralie BELTRAMEET. Beyond Scarcity: Citizen Science Programmes as Useful Tools for Conservation Biogeography. Diversity and Distributions, 2010, roč. 16, č. 3, s. 354-362.

40 Citizen Science in Hydrological Monitoring and Ecosystem Services Management: State of the Art and Future Prospects. Science of The Total Environment, 2019, č. 693, čl. 133531.

41 Citizen science and nature conservation. In MACDONALD, David W. a Katherine J. WILLIS

(eds.). Key Topics in Conservation Biology 2.

Hoboken: John Wiley \& Sons, Ltd., 2013,

s. $127-142$.

42 The Diversity and Evolution of Ecological and Environmental Citizen Science. Plos ONE, 2017, roč. 12 , č. 4 . k chemické analýze společně se všemi nashromážděnými daty. ${ }^{43}$

V České republice probíhá od roku 1914 projekt Kroužkování ptáků, který zastřešuje Kroužkovací stanice Národního muzea.

V současné době se jedná o sít více než čtyř set dobrovolníků, kteří po několikadenním školení a složení závěrečné zkoušky provádí samostatně kroužkování a získaná data ukládají do společné databáze. Nabyté informace vypovídají nejen o výskytu konkrétního druhu, ale také o jeho chování (délka migrace apod.). ${ }^{44}$

V posledních letech je mezi veřejností po celém světě stále populárnější soutěž City Nature Challenge. Jedná se o mapování biodiverzity velkých měst během čtyř dní, kdy účastníci ukládají do mobilní aplikace iNaturalist statisíce pozorování přírody. Od roku 2018 se soutěž s úspěchem koná i v Praze, kde ji organizuje Národní muzeum. ${ }^{45}$

\section{Občanská věda v muzeích}

Jak již bylo předesláno, podobně jako v ostatních vědeckých institucích i v muzeích jsou projekty OV zaměřeny $\mathrm{z}$ velké většiny na přírodovědné obory. V zahraničních muzeích, především v západní Evropě a USA, je zapojení projektů OV do programové nabídky běžnou praxí, a to hned na několika úrovních. Muzeum bud' umožňuje zapojení do konkrétního projektu, který organizuje nebo

\footnotetext{
43 StrawbAIRies [online]. Antwerpen: University of Anwerp, 2021 [cit. 2021-01-27]. Dostupný z www: <https://www.uantwerpen.be/en/ projects/strawbairies/ $>$.

44 CEPÁK, Jaroslav. Atlas migrace ptáků České a Slovenské Republiky. Praha: Aventinum, 2008. 45 Občanská věda: její význam a motivace účastníků v návaznosti na projekt City Nature Challenge. Journal of the National Museum, Natural History Series, 2020, č. 189, s. 49-64; MACEK Ivo a Petra CALTOVÁ. City Nature Challenge. Journal of the National Museum, Natural History Series, 2019, roč. 188, č. 1, s.163-166.
}

se na něm spolupodílí. Příkladem může být Přírodovědecké muzeum v Los Angeles, které organizuje projekty jako GeckoWatch, RASCals, SLIME, Spider Survey nebo Los Angeles Butterfly Survey. Další možností, jak se muzea zapojují do problematiky OV, je popularizace občanské vědy jako takové.

V Oaklandském muzeu v Kalifornii mají zajímavý prodejní automat. Za pět dolarů si zde návštěvníci mohou zakoupit podrobné instrukce a potřebné pomůcky $\mathrm{k}$ zapojení se do konkrétního projektu OV. Nabídka automatu, tedy podklady k projektům, se mění v návaznosti na aktuálně probíhající výstavy. ${ }^{46}$

OV se stává nejen uznávanou metodou vědecké práce, ale zároveň se jedná o užitečný a inovativní přístup spolupráce široké veřejnosti $s$ vědeckými institucemi, muzea nevyjímaje. Zapojení pamětových institucí do živého vědeckého projektu, o jehož průběhu má veřejnost informace, a na kterém se může aktivně podílet, je možností, jak změnit její náhled na aktuální muzejnictví. Muzea jsou i přes svou snahu otevř́ít se veřejnosti často stále vnímána jako konzervativní místa zaměstnávající kurátory, kteří pečují o stávající sbírkový fond a tvoří výstavy. Velká část veřejnosti si pojem "muzeum" pojí jen se samotnou výstavní budovou a nevidí, že je to živý organismus tvořený mnoha profesemi. OV může být cestou, jak si mohou muzea budovat vizitku otevřených institucí. Účastníci občanskovědních projektů např́ič věkovými kategoriemi se seznámí s konkrétními vědeckými pracovníky a jejich pracovní náplní. Získají povědomí o sbírkových fondech a dynamičnosti jejich vývoje. Již samotné zjištění, že se sbírkové fondy neustále

\footnotetext{
46 CAVALIER, Darlene, Catherine HOFFMAN a Caren COOPER. The Field Guide to Citizen Science: How You Can Contribute to Scientific Research and Make a Difference. Portland: Timber Press, 2020.
} 
rozrůstají, jednotlivé artefakty vyžadují preventivní i záchranné konzervační a restaurátorské práce, odborní pracovníci se intenzivně věnují badatelské činnosti a také řeší otázky samotné muzejní prezentace, budí u lidí nevšední zájem. Muzea podporující OV se $\mathrm{z}$ míst, kam se veřejnost přijde vzdělat o vědě, stávají místy, kde veřejnost vědu aktivně provozuje. ${ }^{47}$ Využití principů OV může mít za následek snížení interních nákladů na výzkumnou činnost, a dokonce díky zapojení široké komunity i zrychlení výzkumu (např. získání nebo zpracování enormního množství dat $\mathrm{v}$ poměrně krátkém čase). Na druhou stranu jsou př́pravy dobrého projektu OV často časově, personálně i ekonomicky náročné. Tím se však neliší od jiných aktivit, které muzea směrem $\mathrm{k}$ veřejnosti organizují.

V muzeích se nezřídka setkáváme s tím, že samotní odborní pracovníci nemají o pojmu OV žádné povědomí, a tudíž nejsou schopni zhodnotit, jaký př́ínos by pro ně mohly občanskovědní projekty mít. Dnes je poměrně běžnou praxí realizovat $\mathrm{v}$ muzeích tzv. výzvy $k$ veřejnosti, aby se spolupodílela na tvorbě expozice, výstavy nebo rozšiřování sbírkových fondů tím, že se podělí o předměty, fotografie a dokumenty vážící se k určité problematice. Můžeme zde připomenout výše uvedený projekt Europeana 1989 nebo nedávno realizovanou výzvu Národního muzea Hledáme předmět $s$ př́během, která byla součástí doprovodného programu k Česko-slovenské / Slovensko-české výstavě v roce 2018. O zapojení veřejnosti do příprav výstav usilují i krajská muzea jako např. Muzeum východních Čech v Hradci Králové. To oslovuje dobrovolníky s poptávkou po předmětech

47 COOPER, Caren. Life, Liberty, and Pursuit of Data: The Public Trust of Museum-Based Citizen Science. The Affiliate. News about Smithsonian Affiliates, 2017, č. 4, s. 1-3. nebo fotografiích a dokumentech vážících se $\mathrm{k}$ různým tématům již více jak deset let. Zmínit můžeme výstavy Svoboda přišla $v$ máji (2015), Hurá do školy! (2015/2016) nebo akci spojenou s happeningem Papírová zed' 1989-2019 na připomínku listopadu 1989 v Hradci Králové, jehož symbolem se zde stala spontánně postavená zed' z papírových krabic s revolučními hesly. Všechny tyto akce jsou však jen jednostrannou aktivitou, kdy nedochází k synergii odborných pracovníků a široké veřejnosti. Ta není zpravidla nijak zvlášt obeznámena s využitím jí dodaných materiálů, s postupy katalogizování, ukládáním sbírek a jejich digitalizováním. Jedinou zpětnou vazbou jí bývá to, že darované nebo zapưjčené předměty se stanou součástí instalace, fotografie obohatí multimediální kiosky ve výstavách nebo odborné publikace.

Pokud by odborní pracovníci historických muzeí dokázali uvažovat za hranice těchto výzev a posunuli se blíž k OV, měli by možnost získat mnohem víc. Mohli by dosáhnout partnerského vztahu, zvýšit zájem o svou instituci a povědomí o jejích aktivitách např́ič věkovými skupinami běžných i dosavadně výhradně virtuálních návštěvníků. Právě v tomto bodě se potvrzuje význam zapojení muzejního pedagoga. Ten může sloužit jako mediátor mezi laickou veřejností a odbornými pracovníky. Je schopen zaměřit design projektu OV podle možností, schopností, dovedností a znalostí vybrané cílové skupiny dobrovolníků. Odborně zaměřenou složku projektu tvoří ve spolupráci s kurátory, kteří mají v dané problematice dlouhodobé zkušenosti.

\section{Jak na občanskou vědu?}

Podle definice ICOM je „muzeum nezisková, permanentně působící instituce ve službách společnosti a jejího rozvoje, otevřená veřejnosti, která získává, uchovává, odborně zpracovává, zprostředkovává a vystavuje hmotné a nehmotné dědictví lidstva a jeho životního prostředí za účelem vzdělávání, studia a potěšení“ ${ }^{48}$

Definice sama o sobě nám dává odpověd' na otázku, zda projekty OV patří do muzeí. Jak bylo uvedeno výše, projekty OV jsou vědecké metody zapojující do bádání dobrovolníky z řad široké veřejnosti. Společnost se účastní vědeckých procesů, rozvíjí své znalosti, schopnosti a dovednosti. Jedná se tedy o neziskovou metodu, otevřenou veřejnosti, ve službách jejího rozvoje, získávající a odborně zpracovávající hmotné a nehmotné dědictví lidstva a jeho životního prostředí, a to za účelem vzdělávání, studia a potěšení. To potvrzuje, že projekty OV mohou být nedílnou součástí činnosti pamětových institucí.

Aby muzeum využilo veškerý potenciál $\mathrm{OV}$, je nutné řídit se několika základními principy a organizačními kroky. ${ }^{49} \mathrm{OV}$ je výzkumným př́stupem včetně omezení a zkreslení, které je potřeba brát $\mathrm{v}$ úvahu. Nejvýznamnějším faktorem je spolupráce $s$ širokou veřejností, která nesmí být v rámci této vědecké metody opomíjena. Naopak je ideální maximalizovat zapojení dobrovolníků do jednotlivých fází postupů projektu. Účastníci se v tu chvíli stávají součástí vědeckého týmu a je nutné s nimi podle toho komunikovat (informovat je o výsledcích, dbát na autorská práva, ochranu práv duševního

\footnotetext{
48 Definice muzea [online]. Praha: ICOM Česká republika, 2021 [cit. 2021-01-18]. Dostupný z www: <http://icom-czech.mini.icom.museum/ icom/definice-muzea/>.

49 Deset principů občanské vědy [online]. Berlin: European Citizen Science Association (ESCA), 2020 [cit. 2021-01-23]. Dostupný z www: $<$ https://ecsa.citizen-science.net/wp-content/ uploads/2020/02/ecsa_ten_principles_of_cs_czech. pdf $>$.
} 
vlastnictví, důvěrnost dat apod.). Je nutné, aby proces a výsledky takového projektu byly otevřené, přistupné. A to podobně jako vědecký výstup, který je nedílnou součástí projektu OV, stejně jako v jiných výzkumných přistupech. Spolupráce na projektu musí být př́nosná jak pro odborníky, tak pro dobrovolníky.

\section{Aby se projekty OV v muzeu} staly pravidelnou metodou práce $s$ veřejností, je vhodné zahrnout cíle občanské vědy do strategie a koncepce organizace. Podobně jako v rámci jiných výzkumných přístupů je nutné vytvořit odpovídající design výzkumu. Zhodnotit silné a slabé stránky plánovaného projektu, definovat ekonomické, časové a personální požadavky a stanovit harmonogram projektu. Klíčové je definovat metody motivace budoucích účastníků. Základním kamenem úspěšného projektu OV je dobrá komunikační strategie směrem $\mathrm{k}$ široké veřejnosti. Bez ní nevznikne komunita dobrovolníků, která by se do projektu zapojila. Případně zájem účastníků velmi rychle opadne a projekt OV se stává neúspěšným, ačkoliv všechny ostatní parametry mohly být nastaveny správně.

\section{Závěr}

Jak jsme si již na mnoha tuzemských i zahraničních př́kladech potvrdili, OV není nikterak novým fenoménem. Při pátrání po jejích kořenech je jen potřeba hlubšího sledování podstaty realizovaných aktivit, které byt pod různými označeními, avšak se společnými rysy, odpovídaly charakteru současných občanskovědních projektů.

Zastřešující název „občanská věda" nám umožňuje tyto aktivity vzájemně porovnávat, hodnotit nebo se jimi inspirovat.

V názvu příspěvku jsme si položili otázku, zda projekty OV patří do muzeí? Jak je čtenáři ze samotného textu jistě patrné, snažili jsme se potvrdit, že mají tyto projekty v oblasti kultury významný potenciál. OV se stává jedním z nástrojů, jak mohou pamětové instituce, v našem případě zejména muzea, naplňovat svá poslání a podněcovat zájem veřejnosti o svou činnost. Díky rozmanitosti občanskovědních projektů mohou cílit na skutečné i virtuální návštěvníky, stejně tak jako na občany, kteří se doposud o činnost muzea nezajímali. Otázkou, která stojí za dlouhodobější sledování, zůstává motivace účastníků těchto aktivit. Jak již bylo uvedeno výše, nejedná se jen o zaujetí veřejnosti se do aktivity zapojit, ale o způsoby, jak její zájem udržet po celou dobu konání projektu. Klíčový je design projektu, přizpůsobení jeho náročnosti očekávání, schopnostem, dovednostem a znalostem potenciálních účastníků, ale také podpora, která je po celou dobu konání aktivity dobrovolníkům poskytována. Zkušenost potvrzuje, že pokud mají dobrovolníci pocit, že jsou v dané aktivitě partnery s odborníky, a v případě nesnází i úspěchu obdrží adekvátní zpětnou vazbu, je jejich motivace setrvat $v$ aktivitě vyšší. Intenzitu zájmu veřejnosti ovlivňuje také marketingová strategie projektu, který se prostřednictvím propagace dostává do širšího povědomí veřejnosti. S tím souvisí i finanční náročnost těchto aktivit.

\section{Zajímavým jevem v oblasti} občanskovědních projektů je jejich dominance $\mathrm{v}$ přírodních vědách. Oproti tomu v humanitních a technických oborech jsou zastoupeny marginálně. Pravděpodobné příčiny tohoto jevu byly podrobně rozebrány výše. I přes malé zastoupení občanskovědních projektı̊ $\mathrm{v}$ těchto oborech je možné uvést několik úspěšných aktivit. Jsou to právě př́iklady dobré praxe, které mohou být pro pracovníky pamětových institucí inspirující pro založení vlastního projektu, a to sdílením zkušeností ve všech fázích výzkumu, od jeho příprav, přes realizaci až po vyhodnocení. Odborná diskuse o OV a jejím potenciálu nabízí jednoduchou možnost, jak rozšírit povědomí o jejích výhodách u odborné veřejnosti.

OV dosáhla celosvětového rozšíření. Tomu napomohla flexibilita, kterou tato metoda nabízí. Možnost přizpůsobení vědecko-výzkumných aktivit laické veřejnosti prostřednictvím OV je jednou z jejích velkých devíz. Významným faktorem je zapojení moderních technologií. Mnoho projektů je postavených na využití mobilních telefonů, fotoaparátů nebo počítačů. Tuto elektroniku má k dispozici většina domácností. Zároveň právě díky těmto technologiím je možné do aktivit zapojit prakticky neomezené množství účastníků.

Z hlediska příprav a organizace občanskovědních projektů se ukazuje jako významné zapojení osoby muzejního pedagoga, který se často stává klíčovým mediátorem jednotlivých projektů. Muzea jsou Ministerstvem kultury ${ }^{50}$ podporována $\mathrm{v}$ zaměstnávání kvalifikovaných pracovníků v oblasti vzdělávání a práce s návštěvníkem, protože právě tito zaměstnanci $v$ "první linii“ mají přehled o potřebách, znalostech, schopnostech a dovednostech konkrétních cílových skupin. Jsou kompetentní vytvořit takový design projektu, aby se všichni cítili rovnocennými členy týmu.

$\mathrm{V}$ kapitole Občanská věda v muzeích jsme se setkali s několika př́klady výzev veřejnosti $\mathrm{k}$ zapojení se do

\footnotetext{
50 Koncepce rozvoje muzejnictví $v$ ČR

2015-2020 [online]. Praha: Ministerstvo kultury

ČR, 2021 [cit. 2021-01-20]. Dostupný z www:

$<$ https://www.databaze-strategie.cz/cz/mk/ strategie/koncepce-rozvoje-muzejnictvi-v-ceskerepublice-v-letech-2015-2020>.
} 
příprav výstav nebo veřejných událostí. Pokud by tyto aktivity nebyly jen jednostrannou poptávkou muzeí po artefaktech a byly by metodologicky povýšeny na úroveň občanskovědních projektů, mohly by být mnohem efektivnější.

Závěrem lze říci, že OV představuje pro pamětové instituce obrovský, doposud nevyužitý potenciál, pro který v poslední době vznikají odborné metodiky a doporučení. Významnou podporu $\mathrm{v}$ současnosti představuje možnost čerpání nejen tuzemských, ale i zahraničních grantů.

\section{SEZNAM POUŽITÝCH ZDROJŮ A LITERATURY:}

BRABCOVÁ, Alexandra (ed.). Brána muzea otevřená. Náchod: JUKO, 2003.

ISBN 80-86213-28-5.

British Library - Maps [online]. London: The British Library, 2021 [cit. 2021-01-02].

Dostupný z www: <https://www.bl.uk/ maps/\#>.

CAVALIER, Darlene, Catherine HOFFMAN a Caren COOPER. The Field Guide to Citizen Science: How You Can Contribute to Scientific Research and Make a Difference. Portland: Timber Press, 2020. ISBN 9-781-60469-847-3.

Citizen Science: A Developing Tool for Expanding Science Knowledge and Scientific Literacy. BioScience, 2009, roč. 59, č. 11, s. 977-984.

ISSN 0006-3568. https://doi.org/10.1525/ bio.2009.59.11.9

Citizen science and nature conservation. In MACDONALD, David W. a Katherine J. WILLIS (eds.). Key Topics in Conservation Biology 2. Hoboken: John Wiley \& Sons, Ltd., 2013, s. 127-142. ISBN 9780470658765. https://doi.org/ 10.1002/9781118520178.ch8

Citizen Science in Hydrological Monitoring and Ecosystem Services Management: State of the Art and Future Prospects. Science of The Total Environment, 2019, č. 693, čl. 133531.

ISSN 0048-9697. https://doi.org/10.1016/ j.scitotenv.2019.07.337
Citizen Science in School. In COSTA Manuel F., Josep M. FERNÁNDEZNOVELL a José B. V. DORRÍO (eds.). Hands-on science. Advancing Science. Improving education. Braga: Hands-on Science Network, 2018, s. 194-198. ISBN 978-84-8158-779-1.

Citizen science in the social sciences and humanities: the power of interdisciplinarity. Palgrave Communications, 2020, roč. 6, čl. 89. ISSN 2662-9992. https://doi.org/10.1057/ s41599-020-0471-y

Citizen Science Terminology Matters: Exploring Key Terms. Citizen Science: Theory and Practice [online], 2017, roč. 2, č. 1 [cit. 2021-01-23]. Dostupný z www: <https://theoryandpractice. citizenscienceassociation.org/ articles/10.5334/cstp.96/>.

CEPÁK, Jaroslav. Atlas migrace ptáků České a Slovenské Republiky. Praha: Aventinum, 2008. ISBN 978-80-86858-87-6.

Contributions to conservation outcomes by natural history museum-led citizen science: Examining evidence and next steps. Biological Conservation, 2017, č. 208, s. 87-97. ISSN 0006-3207. https://doi.org/10.1016/j.biocon.2016.08.040

COOPER, Caren. Life, Liberty, and Pursuit of Data: The Public Trust of MuseumBased Citizen Science. The Affiliate. News about Smithsonian Affiliates, 2017, č. 4, s. 1-3.

Definice muzea [online]. Praha: ICOM Česká republika, 2021 [cit. 2021-01-18]. Dostupný z www: <http://icom-czech. mini.icom.museum/icom/definicemuzea/>.

Deset principů občanské vědy [online]. Berlin: European Citizen Science Association (ESCA), 2020 [cit. 2021-01-23]. Dostupný z www: <https://ecsa.citizen-science. net/wp-content/uploads/2020/02/ecsa ten_principles_of_cs_czech.pdf $>$.

DEVICTOR, Vincent, Robert J. WHITTAKER a Coralie BELTRAMEET. Beyond Scarcity: Citizen Science Programmes as Useful Tools for Conservation Biogeography. Diversity and Distributions, 2010, roč. 16 , č. 3, s. 354-362. ISSN 1472-4642. https://doi.org/10.1111/ j.1472-4642.2009.00615.x

DOBREVA, Milena a Daniela AZZOPARDI. Citizen Science in the Humanities: A Promise for Creativity. In
PAPADOPOULOS, George A. (ed.). Proceedings of the 9th International Conference on Knowledge, Information and Creativity Support Systems, Limassol, Cyprus, November 6-8, 2014. Berlin: Springer, 2016.

ISBN: 978-3-319-27477-5.

DUŽÍ, Barbora a Jakub TROJAN. E-manuál komunikace občanské vědy a vybrané příklady dobré praxe. In Občanská věda $v$ České republice [online]. Brno: Ústav geoniky AV ČR, v. v. i., 2020 [cit. 2021-01-23]. Dostupný z www: < https://www.citizenscience. cz/wp-content/uploads/2020/09/CS_ komunikace_e-manual_fin.pdf $>$.

eSbírky - kulturní dědictví on-line [online]. Praha: Národní muzeum, 2021 [cit. 2021-01-02]. Dostupný z www: <htttp://www.esbirky.cz/>.

FALK, John H. (ed.). Free-choice science education: How we learn science outside of school. New York: Teachers College Press, 2001. ISBN 978-0807740644.

FRANZONI, Chiara a Henry SAUERMANN. Crowd science: The organization of scientific research in open collaborative projects. Reasearch Policy, 2014, roč. 43, č. 1, s. 1-20. ISSN 0048-7333.

https://doi.org/10.1016/j.respol.2013.07.005

GOFORTH, Christine L. Getting started in Citizen Science. The Affiliate. News about Smithsonian Affiliates, 2017, č. 4, s. 7.

HAKLAY, Muki. Citizen Science and Volunteered Geographic Information Overview and Typology of Participation. In SUI, Daniel Z., Sarah ELWOOD a Michael F. GOODCHILD (eds.). Crowdsourcing Geographic Knowledge: Volunteered Geographic Information (VGI) in Theory and Practice. Berlin: Springer, 2013, s. 105-122. ISBN 978-94-007-4587-2. https://doi.org/10.1007/978-94-007-4587-2_7 HAND, Eric. People power. Nature, 2010, sv. 466, č. 5, s. 685-687. ISSN 0028-0836. https://doi.org/10.1038/466685a

HECKER, Susanne, Lisa GARBE a Aletta BONN. The European citizen science landscape - a snapshot. In Citizen Science: Innovation in Open Science, Society and Policy. London: UCL Press, 2018, s. 190-200. ISBN 978-1-78735-233-9. https://doi.org/10.2307/j.ctv550cf2.20

HEISS, Raffael a Jörg MATTHES. Citizen Science in the Social Sciences: A Call for More Evidence. Ecological Perspectives for 
Science and Society, 2017, roč. 26, č. 1, s. 22-26. ISSN 0940-5550.

https://doi.org/10.14512/gaia.26.1.7

HSU Chia-Hsuan, Yuan-Mou CHANG a ChiChang LIU. Can Short-Term Citizen Science Training Increase Knowledge, Improve Attitudes, and Change Behavior to Protect Land Crabs? Sustainability, 2019, roč. 11, č. 14 , s. 3918. ISSN 2071-1050. https://doi.org/10.3390/ su11143918

Choosing and Using Citizen Science: a guide to when and how to use citizen science to monitor biodiversity and the environment. Wallingford: Centre for Ecology \& Hydrology, 2014. ISBN: 978-190-669-850-8.

KAUFMANN, Imke a Monika HAGEDORNSAUPE. Citizen Science in Humanities / Unlocking the Knowledge of the Crowd. In WIMM+ Virtual Multimodal Museum [online]. Lemesos: Cyprus University of Technology Cyprus, 2017 [cit. 2021-01-23]. Dostupný z www: < https://www.vi-mm.eu/wp-content/ uploads/2018/05/Citizen-Science-Paper_ AP_IK_MHS_final.pdf $>$.

Koncepce rozvoje muzejnictví $v$ ČR 2015-2020 [online]. Praha: Ministerstvo kultury ČR, 2021 [cit. 2021-01-20]. Dostupný z www: < https://www. databaze-strategie.cz/cz/mk/strategie/ koncepce-rozvoje-muzejnictvi-v-ceskerepublice-v-letech-2015-2020>.

KULHAVÁ, Zdeňka. Muzejní pedagog jako klíčový nástroj v komunikaci s veřejností. In KOCICHOVÁ, Ivana a Marie Žáčková (eds.). Strážci paměti: 200 let muzejnictví $v$ České republice. Perspektivy české muzejní edukace. Sborník příspěvků z konference. Praha: Národní muzeum, 2016, s. 21-30. ISBN 978-80-7036-516-8.

KULHAVÁ, Zdeňka. Pamětník jako cenný zdroj informací i Achillova pata historikova. Možnosti využití orální historie při studiu událostí druhé světové války. In Ústecký sborník historický, 2017, roč. 8, č. 1-2 (v tisku). ISSN 0231-9349.

Lost at night [online]. Cities at night, 2021 [cit. 2021-01-18]. Dostupný z www: $<$ https://lostatnight.org/>.

LUKYANENKO, Roman, Andrea WIGGINS a Holly K. ROSSER. Citizen Science: An Information Quality Research Frontier. Information Systems Frontiers, 2020, č. 22, s. 961-983. ISSN 1387-3326. https://doi.org/10.1007/s10796-019-09915-z

MACEK Ivo a Petra CALTOVÁ. City Nature Challenge. Journal of the National Museum, Natural History Series, 2019, roč. 188, č. 1, s. 163-166. ISSN 1802-6842. https://doi.org/10.2478/jnmpnhs-2019-0010

Motivations for Committed Nature Conservation Action in Europe. Environmental Conservation, 2017, roč. 44, č. 2, s. 148-157. ISSN 0376-8929. https://doi.org/10.1017/S037689291700008X

Občanská věda: její význam a motivace účastníků v návaznosti na projekt City Nature Challenge. Journal of the National Museum, Natural History Series, 2020, č. 189, s. 49-64. ISSN 1802-6842. https://doi.org/10.37520/jnmpnhs.2020.006

Play Artigo, the crowsourcing game of art history [online]. Citizen Science Games, 2019 [cit. 2021-01-18]. Dostupný z www: $<$ https://citizensciencegames.com/ games/artigo/ $>$.

SciStarter, science we can do together. [online]. Tempe: Arizona State University, 2021 [cit. 2021-01-23]. Dostupný z www: $<$ https://scistarter.org/>.

SILVERTOWN, Jonathan. A New Dawn for Citizen Science. Trends in Ecology \& Evolution, 2009, roč. 24, č. 9, s. 467-471. ISSN 0169-5347. https://doi.org/10.1016/ j.tree.2009.03.017

SIMON, Nina. The participatory museum. Santa Cruz: Museum 2.0, 2010. ISBN 9780-0-615-34650-2.

Staré mapy.cz [online]. Brno: Moravská zemská knihovna, 2013 [cit. 2021-01-02]. Dostupný z www: <https://www. staremapy.cz/projekt/>.
STELLE, Lei Lani. Using Citizen Science to Study the Impact of Vessel Traffic on Marine Mammal Populations. In CIGLIANO, John A. a Heidi L. BALLARD (eds.). Citizen Science for Coastal and Marine Conservation. London: Routledge, 2017. ISBN 9781138193222. https://doi.org/10.4324/9781315638966-5

StrawbAIRies [online]. Antwerpen: University of Anwerp, 2021 [cit. 2021-01-27]. Dostupný z www: $<$ https://www.uantwerpen.be/en/ projects/strawbairies/ $>$.

The Current State of Citizen Science as a Tool for Ecological Research and Public Engagement. Frontiers in Ecology and the Environment, 2012, roč. 10, č. 6, s. 291-297. ISSN 1540-9309. https://doi.org/10.1890/110236

The Diversity and Evolution of Ecological and Environmental Citizen Science. Plos ONE, 2017, roč. 12, č. 4. eISSN 1932-6203. https://doi.org/10.1371/ journal.pone.0172579

Výroční zpráva 2014 - Projekt Europeana představí památky na rok 1989 [online]. Praha: Národní museum, 2021 [cit. 2021-01-02]. Dostupný z www: <http:// vyrocnizpravy.nm.cz/2014/sbirkotvornacinnost/projekt-europeana-predstavipamatky-na-rok-1989.html >.

We are ESCA [online]. Berlin: European Citizen Science Association (ESCA), 2020 [cit. 2021-01-23]. Dostupný z www: $<$ https://ecsa.citizen-science.net/ $>$.

What motivates the masses: Understanding why people contribute to conservation citizen science projects. Biological Conservation, 2020, sv. 246, čl. 108587. ISSN 0006-3207. https://doi.org/10.1016/ j.biocon.2020.108587

YAPES - Young Adults‘ Political Experience Sampling [online]. Wien: Universität Wien, 2021 [cit. 2021-01-02]. Dostupný z www: <https://citizenscience.univie. ac.at/projekte-an-der-universitaet-wien/ yapes-young-adults-political-experiencesampling/>. 


\section{PETRA CALTOVÁ}

Přírodovědecké muzeum Národního muzea, Praha, Česká republika

petra.caltova@nm.cz

Petra Caltová pracuje jako muzejní pedagog v Národním muzeu, kde mimo jiné organizuje projekt občanské vědy City Nature Challenge. Neformálnímu vzdělávání se věnovala už během studia, kdy působila na vzdělávacím oddělení Zoologické zahrady hl. m. Prahy.

Petra Caltová works as a museum educator at the National Museum, where she organizes, among other things, the City Nature Challenge citizen science project. She was already engaged in informal education during her studies, when she was working in the Education department of Prague Zoo.

\section{ZDEŇKA KULHAVÁ}

Jilemnická 1223, Lomnice nad Popelkou, Česká republika

zdenka.kulhava@gmail.com

V letech 2017-2019 vedoucí Oddělení vzdělávání a kulturních aktivit Národního muzea, nyní na rodičovské dovolené. Již od roku 2013 se zabývá muzejní pedagogikou a dějinami

19. a 20. století.

Head of Education and Cultural Activities of the National Museum in 2017-2019, now on parental leave. Since 2013, he has been studying museum education and history of the 19th and 20th century.

\section{FRANTIŠEK TYMR}

Oddělení vzdělávání a kulturních aktivit, Národní muzeum, Praha, Česká republika

frantisek.tymr@nm.cz

Vystudovaný antropolog pracuje jako pedagog volného času. Má na starosti edukační programy pro školy a doprovodné programy pro veřejnost nejen $\mathrm{z}$ oblasti př́rodních věd.

A graduated anthropologist, he works as a museum educator. Currently he is in charge of educational programs for schools and events for the public mostly in the field of natural sciences. 